Journal of Contemporary Research in Social Sciences

ISSN : 2641-0249

Vol. 2, No. 4, pp. 81-88.

2020

Publisher: Learning Gate

DOI: $10.33094 / 26410249.2020 .24 .81 .88$

(C) 2020 by the authors; licensee Learning Gate

\title{
Capital Structure and Firms' Performance. A Review of Quoted Nigeria Banks
}

\author{
Abina, Adedigba Praise \\ Finance $\&^{2}$ Banking Department University of Port Harcourt, Port Harcourt Nigeria. \\ Email:praise2009@yahoo.com \\ Akinola Isilamiyat Esther \\ Accounting Department University of Port Harcourt, Port Harcourt Nigeria. \\ Email: hesterakin@gmail.com
}

Received: 7 September 2020; Revised: 30 September 2020; Accepted: 14 October 2020; Published: 27 October 2020

\begin{abstract}
Capital is vital for any business to survive and its composition matters a lot if the business wants to continue in perpetuity. This paper therefore examines capital structure and firms' performance of quoted banks in Nigeria for the period of 1981-2019. It drew heavily from the Static Trade-Off Theory, Irrelevance and Relevance Theory of Modigliani And Miller and the Pecking Order Theory. Secondary data with respect to return on assets, equity ratio and leverage ratio were obtained from the Nigerian stock exchange reports. The data were subjected to unit root tests using the Augmented Dickey-Fuller test and were found to be stationary at first difference: 1(1). The Johansen Co-integration test conducted showed that the variable under study were cointegrated in order 1(1). The results of the Error Correction Model indicated that the debt ratio has negative and insignificant relationship to the return on assets, while the equity ratio and leverage ratio had significant positive relationship to the return on assets proxy for firms' performance. Furthermore, a uni-directional causality was identified between equity ratio and return on assets, equity ratio, debt ratio and leverage ratio and return on assets, after employing the Granger Causality tests. The paper therefore recommends that short-term employment of debt finance is needed so as to easily absorb applicable interest charge and reduce corporate task burden. The paper further suggest that financial managers should rely more on internal funds before exploring other external avenues to source for funds.
\end{abstract}

Keywords: Firm, Debt, Institution, Capital, Structure, Performance, Perpetuity.

\section{Introduction}

Capital structure is basically the composition of debt and equity. The proportion varies according to the organizations involved and the quantum to which they want to source for external fund. There is clear difference between the composition of fund in organized and unorganized financial institution in any economy. Generally, the former holds more capital for liquidity purpose than the later. This is because they extend more credit facility to the deficit economic units than the unorganized financial institution. Capital structure is an array of dissimilar sources of funds open to a given firm as the web of links existing between them. The totality of these funding sources can be shared into two extensive sets namely; debt and equity. Debt refers to that fragment which reflects the total borrowed funds while equity relates to owner-contributed and/or reserved funds. The general relationship existing between borrowed funds (debt) and owner contributed (equity) is known as financial leverage or gearing. There exist different shades of opinion as to whether the structuring of the component funding sources of a firm would affect its value defined in terms of the wealth of the shareholders. In this paper, the wealth of 
the shareholders or firm's value is used to mean the product of the company's current market price and the total outstanding shares of the firm. Shareholders' wealth or firm value is only one aspect of firm performance. The controversies on capital structure range from the relevance/irrelevance effects of capital structuring to the critical roles of the individual components of the funding sources as well as to the relationship between them in terms of leverage. The association between capital structure and bank performance can succinctly be captured with the Agency Cost Theory, Pecking Order Theory and Static Trade-Off Theory. According to Prescott (2001) in the absence of insurance company the thresh-hold that the federal government issue to financial institution mitigate risk the financial institution is likely to face. Modigliani and Miller (1963) opined that the capital structure irrelevance theorem on one hand debunks the influence of the debt-equity division on firm's performance while other theories such as the Trade-Off Theory and Pecking Order Theory point to the fact that debt financing could go a long way in stimulating a firm's performance. This has given rise to the debate over time as to the significance of capital structure as the observed theoretical controversies that have attended the nexus between capital structure and firm value or even performance are far from being resolved. From the above context, it is easy to pin-point the current worry that inform this study. First, empirical studies that have been conducted over time to address the controversies and verification of the theories are still inconclusive and fraught with disagreements, even for evidences in the developed countries, not to talk of developing countries. Furthermore, it is more challenging that the conditions of the developed countries have not been given much attention by researchers. Particularly, studies from developing countries of Africa are not sufficient to establish the tenets and requirements of the theoretical justifications, if applicable. It has also been noticed that the sectoral considerations of the capital structure and firm performance relations are not yet addressed in sufficient numbers to assist in determining possible causes and effects, and other allied issues. Thus, it is not yet fully clear as to which of the theories represent the experiences of firms in developing countries. Most of the few studies seen and reviewed by this paper appear to have adopted inappropriate analytical techniques. The works of Ogbulu and Emeni (2010) and that of Antwi, Ebenezer, Atta, and Xicang (2012) lend credence to the above assertion. Thus, given the scarcity of robust empirical evidence, and in the light of the aforementioned challenges that the present study has been conducted as further studies with more sophisticated methodologies are needed to be carried out drawing empirical evidence from developing countries of Africa such as Nigeria and from certain critical sectors of the economy such as banking. Drawing evidence from banks listed on the Nigeria Stock Exchange in order to attempt to provide fresh answers to the same old questions. Does the decomposition of capital into debt and equity affect the performance or value of firms operating in the banking sector of the economy? Which of the funding sources affect performance or value more and in what direction? Empirical works have shown that firms that do not have quality and sound capital structure overtime will go into liquidation after four years of operation. This paper intends to investigate Capital Structure and Firm Performance of Quoted Nigerian Banks.

\section{Theoretical Review}

\subsection{Static Trade-Off Theory}

The value of the firm is exogenous of the capital mix of the company. This theory was propounded by Modigliani. and Miller (1958) which was later reviewed in 1963. They came up with this illustration, that firm that have the potential of going into continuity (long term investment) and have huge profit margin ratio should be financed by debt. This firm replaced equity for debt in order to get advantage of tax shield which will cut down the burden on equity financing. Kyereboah (2007) discovered that firms cash flow is not affected by this mix. In an attempt to uncover the circumstances that necessitate the above assertion, Barclay and Smith (2005) discovered that these circumstances might be categorized into either a deliberate act, an artificial act or asymmetric information cost. In the works of Myers and Majluf (1984) they attempt to balance the disequilibrium that might exist as a result of bankruptcy cost and tax shield benefit. Stiglitz (1974) discovered that bankruptcy costs increase as the debt employed get higher. 


\subsection{Irrelevant and Relevant Theory}

This theory challenged the traditional view of the capital structure theory. It was propounded by Modigliani. and Miller (1958). As the name implies, this states that the firm's value is not affected by the financial mix component. It assumes that transaction costs, bankruptcy costs and taxation costs do not exist. It also witnessed that the asymmetry information is not present.

\subsection{The Pecking-Order Theory}

The cost of information concerning a particular security is dependent on the riskiness associated with such security (Myers \& Majluf, 1984). This theory states that information asymmetry is what determines the riskiness of such claim. Asymmetry information that is noticeable between the outsider and insider in the firm is a major determinant of the fluctuation or direction that can be traceable to how the price of security fluctuates. This theory makes room for internal fund to any financing option that the company tend to use if there is need to raise fund. Moreover, if there is need to raise fund, they switch to risk-free fund before low-risk fund. Whenever a firm's retained earnings become insufficient, there is need for such firm to switch to the use of debt as an alternative instrument and as last alternative to financing the operation of the company. Hovakimian (2006) discovered that timing is irrelevant in the composition of equity.

\subsection{Market Timing Theory}

This theory depicts that the undervaluation of capital structure requires firms to buy back their initial shares that was issued out to the public during the period the price is overvalued (Baker \& Wurgler, 2002). The fluctuation noticeable between the period of overvaluation and undervaluation is a major determinant of firm's financial mix. The market timing and stock return plays an important role in determining a flexible capital structure. This view was discredited by Hovakimian (2006) who discovered that market timing will eventually fade out on the long run.

\subsection{Agency Cost Theory}

This theory was developed by Jensen and Meckling (1976). The theory suggests that ownership formation is a basic determinant of capital mixture in a company. They also placed more emphasis on a better mixture of debt and equity and why debt should be used for financing. Arising from the conflict that is attributed to the parties involved in running the affairs of a company (shareholders and managers), it can be seen that since the managers are responsible for the major objective of a business which is wealth maximization and the ratio of their share to that of the owners cannot be compared, they decide to pursue more of perquisites rather than increase the shareholders' profit. The discretion noticeable in the process of managers carrying out their duty can be mitigated if the proportion of debt is increased to a reasonable extent. Peradventure, shareholders invest in less productive investment this will instigate debt holders to react since their interest is fixed. Also, if an investment return is above the debt face-value, a good proportion of the profit is accruable to the shareholders but if the reverse is the case, the debt holders will bear the full cost. This is because the amount shareholders can lose is attributable to their investment in such project. Highly risky project (asset substitution effect) might be the order of the day since the consequence (loss) is not borne by the shareholders but the debt holders bears the burden that springs forth from such investment.

\subsection{Empirical Review}

Aremu, Ekpo, Mustapha, and Adedoyin (2014) examined five (5) banks' capital structure between the period 2006-2010. They made use of pooled Ordinary Least Square Technique for analysis and it was discovered that capital structure is basically influenced by policy makers, financial analysts and bank managers. Secondly it was discovered that dividend payout, tax charge factors, tangible assets, bank size and business risk are major determinant of capital structure. In Nigeria, Muritala (2012) investigates 10 firms and their performance when leverage is used in financing their operations. 
Employing the use of panel data from 2006-2010, they discovered that debt has an undesirable affiliation with total asset ratio on return on assets. Similar result was discovered in the works of Soumadi and Hayajneh (2012) who discovered an undesirable influence between Tobin's $Q$ and return on equity. Hossain and Hossain (2015) discovered that in Bangladesh, manufacturing firms follow the Static Trade-Off and Pecking Order Theories. Textile company in Pakistan was studied by Abbas, Bashir, Manzuor, and Akram (2013) were they discovered that risk, size, leverage and debt shield affects the performance of firms in the country. In New Zealand, similar finding was identified by Safarova (2010) but he added that corporate governance and cash at hand are also performance determinants while Mirza and Javed (2013) added that firm's financial mix is determined by proper management of risk. Siddik, Alam, Kabiraj, and Joghee (2017) made use of panel data, which were sourced from 22 banks in Bangladeshi for the period of 2005-2014. The Levin-Lin-Chu (LLC) unit root test was employed. Likewise, the Pooled Ordinary Least Square technique was employed in the analysis. An inverse relationship was observed between the various debt obligations to total assets that were used in their study. They asserted that these debt obligations reduce earnings per share and return on equity and the study agrees with the findings of Hasan, Ahsan, Rahaman, and Alam (2014). Salim and Yadav (2012) discovered that there is need for firms to have large size of capital because this will enhance their growth opportunities. Macroeconomic variable was also employed and an inverse relationship was identified. The study concludes that plummeting of debt is advised and managers should make use of retain earnings to finance its further operation and if there is need for additional capital they should employ debt as their last resort.

\section{Research Methodology}

This study used the ex-post facto research design. Secondary data gotten from the Nigeria's Stock Exchange reports on fifteen (15) quoted banks which were utilized in this study. In line with the threebasic underpinning theories and to ascertain the mutual relationship that exists between capital structure of banks and their performance the following can be modeled out. Return on Asset (ROA) was used as proxy for the endogenous variable while equity ratio (EQR), debt ratio (DTR) and leverage ratio (LEV) were used as proxy for the exogenous variable.

\subsection{Method of Data Analysis}

The order of stationarity was first ascertained in this paper since it's a prerequisite for evaluating long-run relationships as well as Granger Causality test and as such, the Augmented Dickey-Fuller test statistic was utilized to ascertain the usability of the data while the Error Correction Model (ECM) was used to determine the stochastic trend in the two model and finally, the granger causality test establish if the past values of $\mathrm{Q}^{1}$ contain information that helps predict the future outcome of $\mathrm{Q}^{2}$.

\subsection{Model Specification}

\subsubsection{Functional, Mathematical and Econometric form of the Model}

Equations 1 and 2 below shows the operational model that specifies the relationship between the slope and the intercept which is modeled in two different equations thus, presented as follows:

$$
\begin{array}{ll}
\mathrm{ROA}= & \mathrm{F}(\mathrm{EQR}, \mathrm{DTR}) \\
\mathrm{ROA}= & \mathrm{F}(\mathrm{LEV})
\end{array}
$$

For econometric purposes, Equations 1 and 2 can further be transformed to an econometric form after which the constant and the error term is included thus, presented and modeled in Equations 3 and 4 below;

$$
\begin{aligned}
& \mathrm{ROA}_{\mathrm{t}}=\ddot{w}_{\mathrm{o}}+w_{1} \mathrm{EQR}_{\mathrm{t}}+\varpi_{2} \mathrm{DTR}_{\mathrm{t}}+\mu_{\mathrm{t}} \\
& \mathrm{ROA}_{\mathrm{t}}=\partial_{\mathrm{o}}+\partial_{1} \mathrm{LEV}_{\mathrm{t}}+\pi_{\mathrm{t}}
\end{aligned}
$$

On apriori $\boldsymbol{w}_{1,2,}>0 \partial_{1}>0$ for both models.

Where:

$\boldsymbol{w}_{\mathrm{o} \text { and }} \partial_{\mathrm{o}}=$ Constant, $\boldsymbol{w}_{\mathrm{i}}-\boldsymbol{w}_{2}=$ Estimation parameters, $\mu_{\mathrm{t}}$ and $\pi_{\mathrm{t}}=$ Random variables or Error term. 


\section{Presentation of Empirical Findings}

\subsection{Unit Root Test (Augmented Dickey-Fuller Test)}

The unit root test is employed to ascertain the usability of the data and the likelihood of shocks that ought to disappear in a short period of time.

Table-1.

Presentation of unit root result.

\begin{tabular}{c|c|c|c|c|c|c}
\hline \multicolumn{3}{|c|}{ ADF Test } & & \multicolumn{3}{c}{ Test Critical Values: } \\
\hline KEY & T-Statistic & Stationary & Prob.* & 1\% level & 5\% level & 10\% level \\
\hline $\mathrm{D}(\mathrm{ROA})$ & -7.166097 & $1(1)$ & 0.0000 & -3.679322 & -2.967767 & -2.622989 \\
\hline $\mathrm{D}(\mathrm{EQR})$ & -5.027589 & $1(1)$ & 0.0003 & -3.679322 & -2.967767 & -2.622989 \\
\hline $\mathrm{D}(\mathrm{DTR})$ & -4.543442 & $1(1)$ & 0.0012 & -3.679322 & -2.967767 & -2.622989 \\
\hline $\mathrm{D}(\mathrm{LEV})$ & -3.799982 & $1(1)$ & 0.0075 & -3.679322 & -2.967767 & -2.622989 \\
\hline
\end{tabular}

From the Table 1, it can be inferred that the variables attain stationarity at level 1(1). This means that the data can be used for further forecast in the future.

\subsection{Johansen Co-Integration Test}

Table-2.

Presentation of Co-Integration result.

\begin{tabular}{|c|c|c|c|c|}
\hline \multicolumn{5}{|c|}{ MODEL 1} \\
\hline Hypothesized & No. of CE(s) & None $*$ & At most 1 & At most 2 \\
\hline & Eigenvalue & 0.535659 & 0.651501 & 0.299163 \\
\hline Trace & Statistic & 31.43505 & 61.34111 & 9.953429 \\
\hline \multirow[t]{2}{*}{0.05} & Critical Value & 25.87211 & 47.85613 & 12.51798 \\
\hline & Prob.*** & 0.0091 & 0.0017 & 0.1293 \\
\hline \multicolumn{5}{|c|}{ MODEL 2} \\
\hline \multirow[t]{2}{*}{ Hypothesized } & No. of CE(s) & None $*$ & At most 1 & At most 2 \\
\hline & Eigenvalue & 0.678263 & 0.404339 & 0.299163 \\
\hline Trace & Statistic & 56.21231 & 24.45975 & 9.953429 \\
\hline \multirow[t]{2}{*}{0.05} & Critical Value & 42.91525 & 25.87211 & 12.51798 \\
\hline & Prob.*** & 0.0014 & 0.0742 & 0.1293 \\
\hline
\end{tabular}

From the results of both models shown in Table 2 above, we can conclude that there is one cointegrating equation. This means joint stochastic trend can be seen which supports the assertion of Gujarati (2004) and Koutsoyiannis (2001). That if there is at least one co-integrating equation in the model, then it can be concluded that there is long run association/connection among the variables under investigation. Model one has two, while model two has one co-integrating equation thus, the Error Correction Model (ECM) is conducted. This test helps to correct the distortion between the short run and long run.

\subsection{Error Correction Model (ECM)}

The result of the ECM in Table 3 above displays that DTR at lag -1 has a negative co-efficient of 0.000131 and an insignificant relationship (probability value of 0.6354) with the ROA. The same result with different value can be seen at lag -2 . This means the proportion of debt in the financial system investigated have an adverse effect on their profit. For every one Naira borrowed outside the ownership of the bank, it reduces it profit in lag -1 by $-0.000131 \%$ while lag -2 is by -2.886605 . This finding does 
not support the Static Trade-Off Theory propounded by Modigliani and Miller model. Using $10 \%$ confidence level, EQR has a significant relationship with ROA.

Table-3.

Presentation of error correction result (MODEL 1).

\begin{tabular}{c|c|c|c|c}
\hline Indicators & Coefficient & Std. Error & t-Statistic & Prob. \\
\hline $\mathrm{D}(\mathrm{DTR}(-1), 2)$ & -0.000131 & 0.000272 & -0.481854 & 0.6354 \\
\hline $\mathrm{D}(\mathrm{DTR}(-2), 2)$ & -2.880005 & 0.000234 & -0.123262 & 0.9032 \\
\hline $\mathrm{D}(\mathrm{EQR}(-1), 2)$ & 0.007531 & 0.002521 & 2.986713 & 0.0064 \\
\hline $\mathrm{D}(\mathrm{EQR}(-2), 2)$ & 0.557222 & 0.098501 & 5.657058 & 0.0000 \\
\hline
\end{tabular}

But at $5 \%$ confidence level, it can be seen that at lag -1 we accept the null hypothesis while at lag -2 we accept the alternate hypothesis. Using either of the confidence level $5 \%$ or $10 \%$ it can be seen that a negative relationship is attributed to both lags. EQR has a positive (co-efficient of $0.00753,0.557222$ ) and significant relationship (probability value of $0.0064,0.0000$ ) with ROA in both lags. This finding is in consonance with Pecking-Order Theory which states that firms prefer financing through internal funds rather than borrowed fund. The equity capital represents owner's capital or business owners' equity financing which contributes tremendously to performance of the banking sector. Exceedingly, this theory also states that before a firm goes outside to source for funds, it must have used up its equity reserve. It also accepts (Bauer, 2004) who discovered that in order for there to be future growth opportunities in any business venture, there is need to use more of equity financing rather than debt. Similarly, Anderson and Williamsson (2001) opined that banks prefer to use retained earnings to undertake their investment opportunities instead of borrowed fund. It can also be seen that modern financial techniques have helped financial managers anticipate and calculate the variability of risk that might spring out of embarking on any choice of capital mix. These findings negate Expense theory of Williamson (1963). It also negates the Irrelevant and Relevant Theory of Modigliani. and Miller (1958).

Table-4.

Presentation of error correction result (MODEL 2).

\begin{tabular}{c|c|c|c|c}
\hline Indicators & Coefficient & Std. Error & t-Statistic & Prob. \\
\hline $\mathrm{D}(\mathrm{LEV}(-1), 2)$ & 0.068148 & 0.006501 & 10.48331 & 0.0033 \\
\hline $\mathrm{D}(\mathrm{LEV}(-2), 2)$ & 1.146212 & 0.155218 & 7.384525 & 0.0006 \\
\hline
\end{tabular}

\subsection{Causality Tests}

Table-5.

Presentation of pairwise granger causality test result (MODEL 1).

\begin{tabular}{|c|c|c|c|}
\hline Null Hypothesis: & Obs & F-Statistic & Prob. \\
\hline DTR does not Granger Cause ROA & 30 & 1.24477 & 0.3053 \\
\hline \multicolumn{2}{|l|}{ ROA does not Granger Cause DTR } & 0.53430 & 0.5926 \\
\hline EQR does not Granger Cause ROA & 30 & 3.42411 & 0.0415 \\
\hline \multicolumn{2}{|l|}{ ROA does not Granger Cause EQR } & 1.61613 & 0.2187 \\
\hline EQR does not Granger Cause DTR & 30 & 5.09193 & 0.0140 \\
\hline \multicolumn{2}{|l|}{ DTR does not Granger Cause EQR } & 0.85987 & 0.4354 \\
\hline
\end{tabular}

Decision Rule: If the p-value is < than 0.05, we reject the null hypothesis but if not, we do no reject it. From the above Table 5, the result of granger causality test shows that DTR does not granger cause ROA neither does ROA granger cause DTR at $5 \%$ confidence level. Also EQR cause a change in ROA 
but ROA does not cause a change in EQR. Finally, EQR cause a change in DTR but DTR does not cause a change in EQR. This means past values of EQR can cause a change in ROA. Likewise, EQR can cause a change in DTR.

Table 4 above shows the ECM result of model 2 which upholds Modigliani and Miller (M-M) Irrelevance and Relevance Theory which states that internal and external fund are irrelevant and that the capital structure of firm should not be a determinant of the value of any firm. It was discovered that leverage is important for banks to perform effectively in their operations. The VECM output shows that there is a positive co-efficient of 0.068148 and a significant (P-value of 0.0033 ) relationship, this means for every one percent increase in LEV, it leads to an increase of about $0.068148 \%$ in ROA of banks under investigation, same relationship is identified in lag -2 as the finding accepts (Abbas et al., 2013; Fosu, 2013).

\subsection{Causality Tests}

Table-6.

Presentation of pairwise granger causality test result (MODEL 2).

\begin{tabular}{l|l|c|c}
\hline Null Hypothesis: & Obs & F-Statistic & Prob. \\
\hline LEV does not Granger Cause ROA & 30 & 7.28487 & 0.0032 \\
\hline ROA does not Granger Cause LEV & & 3.15496 & 0.0600 \\
\hline
\end{tabular}

From the granger causality result displayed in Table 6 above it can be seen that LEV causes a change in ROA while ROA does not also cause a change in LEV at 5\% confidence level.

\section{Discussion Conclusion and Recommendation}

This research paper made use of two different models in which the results are methodologically presented in two different models. The first test carried out is the unit root test which is used to determine the usability of the data for estimation purpose on the long run. The result of the (ADF) test shows that the variables were stationary at first difference which are summarized in Table 1 . In order to ascertain the long run relationship among the variable of study, the Johansen Co-integration result was employed. It was discovered that one co-integrating equations was identified in model 1 and 2 , this further led to the conduct of Error Correction Model (ECM) which shows the direction and speed of adjustment between the short and long period. This test was used to accept or reject the hypotheses. From the first model it can be summarized that debt-capital has a negative (co-efficient of -0.000131\%) and an insignificant (P-value of 0.6354) relationship with return on asset in both lags. These findings do not support (Saeed, Gull, \& Rasheed, 2013) who discovered a contrary relationship between debt to capital ratio. The Static Trade-Off Theory propounded by Modigliani and Miller is theoretically dislodged. It was also discovered that financing the business with owner's capital is more beneficial than seeking funding from external sources. EQR has a positive and significant relationship in both lags supporting Pecking-Order Theory. Finally, the second model shows that a positive (co-efficient of 0.068148 ) and significant (P-value of 0.0033) relationship exist between leverage variable and return on equity. This upholds the Irrelevance and Capital Structure Theory of Modigliani and Miller (M-M). A similar discovery was identified in the work of Abbas et al. (2013); Fosu (2013). In the second model, it was discovered that a uni- directional causality was seen between ROA and LEV. However, in the first model, one-way causality was identified between EQR and ROA, the same direction was seen between EQR and DTR. Based on the research findings, this paper therefore recommends that in order for the burden of tax to be mitigated, debt financing in banks ought to be on a short-term basis so as to keep up the payment of interest that is attached to its usage. There is also the need for financial managers to rely more on internal funds before exploring other external avenue to source for funds. 


\section{References}

Abbas, A., Bashir, Z., Manzuor, S., \& Akram, M. N. (2013). Determinants of firm's financial performance. An empirical study on textile sector of Pakistan. Business and Economic Research, 3(2), 77 -86.Available at: https://doi.org/10.5296/ber.v3i2.3958.

Anderson, M., \& Williamsson, M. (2001). Kapitalstrucktur SMEs. Master Thesis, Jonkoping Jonkoping International Business School, Jonkoping University.

Antwi, S., Ebenezer, F. E., Atta, M., \& Xicang, Z. (2012). Capital structures and firm value. Empirical evidence from Ghana. International Journal of Business and Social Science, 3(22), 103-111.

Aremu, M. A., Ekpo, I. C., Mustapha, A. M., \& Adedoyin, S. I. (2014). Determinants of capital structure in Nigerian banking sector. International Journal of Academic Research in Economics and Management Sciences, 2(4), 27-37.Available at: https://doi.org/10.6007/ijarems/v2-i4/50.

Baker, M., \& Wurgler, J. (2002). Market timing and capital structure. Journal of Finance, 1(57), 1-32.Available at: https://doi.org/10.1111/1540-6261.00414.

Barclay, M. J., \& Smith, C. W. (2005). The capital structure puzzle: The evidence revisited. Journal of Applied Corporate Finance, 17(1), 8-17.Available at: https://doi.org/10.1111/j.1745-6622.2005.012_2.x.

Bauer, P. (2004). Determinants of capital structure: Empirical evidence from the Czech Republic. Czech Journal of Economics and Finance (Finance a uver), 54(1-2), 2-21.

Fosu, S. (2013). Capital structure, product market competition and firm performance: Evidence from South Africa. The Quarterly Review of Economics and Finance, 53(2), 140-151.Available at: https://doi.org/10.1016/j.qref.2013.02.004.

Gujarati, D. (2004). Basic econometrics (4th ed.). New York: McGraw-Hill.

Hasan, M. B., Ahsan, A. F. M., Rahaman, M. A., \& Alam, M. N. (2014). Influence of capital structure on firm performance. Evidence from Bangladesh. International Journal of Business. Management, 5(9), 184-194.Available at: https://doi.org/10.5539/ijbm.v9n5p184.

Hossain, I., \& Hossain, M. A. (2015). Determinants of capital structure and testing of theories: A study on the listed manufacturing companies in Bangladesh. International Journal of Economics and Finance, 7(4), 176-190.Available at: https://doi.org/10.5539/ijef.v7n4p176.

Hovakimian, A. (2006). Are observed capital structures determined by equity market timing? The Journal of Financial and Quantitative Analysis, 41(1), 221-243.Available at: https://doi.org/10.1017/So022 109000002489.

Jensen, M. C., \& Meckling, W. H. (1976). Theory of the firm: Managerial behavior, agency costs and ownership structure. Journal of Financial Economics, 3(4), 305-360.Available at: https://doi.org/10.1016/0304-405x(76)90026-x.

Koutsoyiannis, A. (2001). Theory of econometrics (2nd ed.). New York: Patagrave.

Kyereboah, C. A. (2007). Corporate governance and firm performance in Africa. A dynamic panel data analysis. International Conference on Corporate Governance in Emerging Markets. Sabanci University, Istanbul, Turkey.

Mirza, S. A., \& Javed, A. (2013). Determinants of financial performance of a firm: Case of Pakistani stock market. Journal of Economics and International Finance, 5(2), 43-52.Available at: https://doi.org/10.5897/jeif 12.043.

Modigliani, F., \& Miller, M. H. (1963). Corporate income taxes and the cost of capital: A correction. The American Economic Revier, 53(3), 433-443.

Modigliani., F., \& Miller, M. (1958). The cost of capital, corporation finance, and the theory of investment. American Economic Revier, 1(48), 261-197.

Muritala, T. A. (2012). An empirical analysis of capital structure on firms' performance in Nigeria. International Journal of Advances in Management and Economics, 1(5), 116-124.

Myers, S., \& Majluf, N. (1984). Corporate financing and investment decisions when firms have information that investors do not have. Journal of Financial Economics, 13(2), 187-221.Available at: https://doi.org/10.1016/0304-405x(84)90023-0.

Ogbulu, O. M., \& Emeni, F. (2010). Ownership structure and the performance of quoted companies in Nigeria. International Journal of Business and Behavioral Sciences' Research, 1(1), 60-73.

Prescott, E. S. (2001). Regulating bank capital structure to control risk. FRB Richmond Economic Quarterly, 87(3), 35-52.

Saeed, M. M., Gull, A. A., \& Rasheed, M. Y. (2013). Impact of capital structure on banking performance (A case study of Pakistan). Interdisciplinary Journal of Contemporary Research in Business, 4(10), 393-403.

Safarova, Y. (2010). Factors that determine firm performance of New Zealand listed companies. Dissertation Submitted to Auckland University of Technology.

Salim, M., \& Yadav, R. (2012). Capital structure and firm performance: Evidence from Malaysian listed companies. ProcediaSocial and Behavioral Sciences, 65, 156-166.Available at: https://doi.org/10.1016/j.sbspro.2012.11.105.

Siddik, M., Alam, N., Kabiraj, S., \& Joghee, S. (2017). Impacts of capital structure on performance of banks in a developing economy: Evidence from Bangladesh. International Journal of Financial Studies, 5(2), 1-18.Available at: https://doi.org/10.3390/ijfs5020013.

Soumadi, M. M., \& Hayajneh, O. S. (2012). Capital structure and corporate performance empirical study on the public Jordanian shareholding's firms listed in the Amman stock market. European Science Journal, 8(2), 173-189.

Stiglitz, J. E. (1974). On the irrelevance of corporate financial policy. The American Economic Revierw, 64(6), 851-866.

Williamson, O. E. (1963). Managerial discretion and business behavior. The American Economic Review, 53(5), $1032-1057$. 